\title{
KELURAHAN KENDANGSARI MENUJU KAMPUNG PELANGI SURABAYA SEBAGAI UPAYA PERBAIKAN LINGKUNGAN KOTA MELALUI STRATEGI KAMPUNG KREATIF
}

\author{
Kendangsari Towards Surabaya's Rainbow Village As An Effort To Improve City's \\ Environment Through Creative Strategies \\ Elida Ulfiana ${ }^{1}$, Eka Mishbahatul M Has ${ }^{1}$, Makhfudli ${ }^{1}$, Ferry Efendi ${ }^{1}$ \\ ${ }^{1}$ Fakultas Keperawatan, Universitas Airlangga, Surabaya \\ Email : elida_u@fkp.unair.ac.id
}

\begin{abstract}
ABSTRAK
Lingkungan perumahan yang padat serta rendahnya perilaku warga menjaga kebersihan lingkungan serta belum adanya pengelolaan sampah rumah tangga membuat pemandangan yang kurang indah dipandang di wilayah Kendangsari Surabaya. Solusi untuk menyelesaikan masalah tersebut adalah dengan pendekatan strategi kampung kreatif membentuk kelurahan Kendangsari menuju kampung Pelangi di Surabaya. Tujuan Pengabdian Masyarakat ini adalah merintis Kelurahan Kendangsari menjadi Kampung Pelangi dengan lingkungan bersih, asri bernuansa warna warni, meningkatkan perilaku kebersihan lingkungan, serta membangun kreativitas warga. Target kegiatan yang dilakukan adalah kerjabakti pengecatan, sosialisasi Bank sampah, serta pelatihan pembuatan batik celup. Kegiatan dilaksanakan di RT 03 RW 04 Kelurahan Kendangsari sebagai daerah rintisan kampung pelangi. Metode dalam pelaksanaan pengabdian masyarakat menggunakan tahapan strategi kampung kreatif yaitu pembentukan ide kreatif, realisasi ide kreatif, penguatan sistem pendukung, penguatan sistem pendukung, penyediaan ruang basis aktivitas kreatif, dan ealuasi aktivitas kreatif. Pada akhir tahap evaluasi dapat dilihat secara langsung satu wilayah telah bernuansa warna warni, adanya upaya membentuk unit bank sampah, serta adanya ketrampilan warga membuat batik celup.
\end{abstract}

Kata kunci : Kampung pelangi, Kendangsari, Surabaya, kreatif

ABSTRACT

Kendangsari is one of the villages in Surabaya City which is less beautiful to see. It is dense with slum housing and looks dirty. The community still has a low awareness to maintain the cleanliness of their environment. There also do not well understand waste management. By using creative strategies approach, Kendangsari was expected to be Surabaya's Rainbow Village. This community services aimed to initiate Kendangsari Village toward Surabaya's Rainbow Village with clean, green, and colorful nuances environment, where the peoples have good behavior in hygiene and sanitation, and also creative. Activities that have been carried out was the wall and house painting, socialization for waste bank program, and training to make a shibori batik. Events were held on RT 03 RW04 Kendangsari Village as an initial area to be a rainbow village. The method consists of strategies, that is building creative ideas, realizing creative ideas, building a support system, providing basecamp for creative activities, and evaluating creative activities. At the end of the evaluation, Kendangsari was transformed as a colorful village, it has a unit to manage a waste bank, and there were a group of women who able to make Shibori batik.

Keywords : Rainbow village, Kendangsari, Surabaya, creative.

\section{PENDAHULUAN}

Kampung merupakan kelompok rumah yang merupakan bagian kota (biasanya dihuni orang berpenghasilan rendah). kampung kota adalah suatu bentuk pemukiman di wilayah perkotaan yang khas Indonesia dengan ciri antara lain: penduduk masih membawa sifat dan prilaku kehidupan pedesaan yang terjalin dalam ikatan kekeluargaan yang erat, kondisi fisik bangunan dan lingkungan kurang baik dan tidak beraturan, kerapatan bangunan dan penduduk tinggi, sarana pelayanan dasar serba kurang, seperti air bersih, saluran air limbah dan air hujan, pembuangan sampah dan lainnya (Heryati,2011) 
Kampung pelangi adalah kampung dengan konsep warna warni. Tren kampung warna warni mulai banyak dikembangkan. Kampung pelangi merupakan strategi untuk merubah kampung yang dulunya kumuh menjadi lebih bersih sehat bahkan menjadi destinasi wisata. Di Jawa Timur ada Kampung Jodipan Malang, Kampung Kelir Kroman Grasik, Kampung sungai Kalilo Banyuwangi dan kampung Kenjeran Surabaya. Di Jawa Tengah ada Desa Wisata Bejalen Ambarawa dan Kampung Warna Wonosari di Semarang, dan di beberapa kota lain seperti di Lubuk Linggau dan Kampung Teluk Seribu di Balikpapan.

Kelurahan Kendangsari merupakan kelurahan di kecamatan Tenggilis Mejoyo di wilayah Surabaya Timur. Penduduk di kecamatan Tenggilis Mejoyo paling banyak bekerja menjadi karyawan swasta sebanyak 19261 (52,6\%), mereka bekerja di pabrik industri di daerah rungkut dan sekitarnya. Pertumbuhan penduduk di kecamatan Tenggilis Mejoyo merupakan pertumbuhan penduduk yang tinggi dengan lebih dari $2 \%$. Jumlah penduduk di kelurahan Kendangsari sebanyak 16.455 orang dengan 4.527 keluarga. Penduduk di kelurahan Kendangsari berdasarkan pekerjaan paling banyak adalah ibu rumah tangga 2.983 orang, pekerja swasta 1.650 orang bekerja di pabrik industri, dan sebagai pelajar 1.173 orang. Tingkat pendidikan sebagian besar tingkat SMP-SMA. Kelurahan Kendangsari dengan luas wilayah 130.614 Ha terdiri dari $5 \mathrm{RW}$ dan termasuk dalam pemukiman padat penduduk. Warga masih menggunakan sungai/ parit untuk membuang sampah, rumah yang satu dengan yang lainnya tidak memiliki jarak sehingga terkesan padat dan menyebabkan adanya tumpukan sampah di depan rumah. Belum adanya sistem pengelolaan sampah menyebabkan warga membuang sampah organik dan non organik pada bak sampah yang sama (KKN BBM Tematik 57, 2017).Kelurahan kendangsari memiliki beberapa kelompok pengorganisasian mulai dari kelompok karang taruna, PKK, sampai Karang Werdha yang aktif melakukan kegiatan untuk kesejahteraan warga. Dalam sistem pemerintahan kelurahan kendangsari aktif melakukan koordinasi dari kelurahan sampai tingkat RW dan RT. Bahkan kerjasama lintas sektor baik di bidang Kesehatan, pendidikan, keamanan dan kesejahteraan sosial dilakukan secara aktif dalam bentuk program-program yang diterapkan ke seluruh warga.

Berdasarkan uraian diatas, maka kelurahan kendangsari memiliki potensi untuk menyelesaikan permaslahan. Pemukiman yang padat penduduk dapat dilakukan modifikasi dengan strategi yang kreatif dengan mengubah kelemahan menjadi kekuatan. Lingkungan yang belum bersih akibat perilaku warga yang tidak sehat tentang pengelolaan sampah dapat dirubah melalui proses perubahan perilaku sehat melalui pengelolaan Bank sampah.. Proses pemberdayaan masyarakat dapat dilakukan dengan sasaran proporsi terbanyak adalah ibu rumah tangga yang tidak bekerja. Hal ini ditunjang dengan adanya kelompokkelompok yang dapat menunjang mulai dari remaja karang taruna, ibu-ibu PKK, LKMK, dan karang werdha. Warga yang tinggal di kelurahan kendangsari adalah sebagian besar penduduk asli dan sebagian warga musiman yang berasal dari surabaya, dan rasa gotong royong seperti kerjabakti masih tampak di kelurahan kendangsari. Hal ini menunjukkan bahwa warga masih berpotensi dengan motivasi untuk berperilaku menjaga lingkungan bersih sehat.

\section{METODE PELAKSANAAN}

Pendekatan metode yang dilaksanakan pada kegiatan pengabdian masyarakat ini adalah pemberdayaan, melibatkan pihak kelurahan Kendangsari dan warga RT 03 RW 04 Kelurahan Kendangsari. Bentuk kegiatan yang diterapkan adalah strategi kampung kreatif yang melalui lima tahapan berdasarkan Cycle of Urban Creativity yaitu :

1. Pembentukan ide kreatif ; tahap pengenalan dan pengembangan kreativitas pada masyarakat sebagai solusi permasa-lahan. Tahap ini dimulai dengan adanya inisiator berupa individu ataupun komunitas yang mem-bantu membangkitkan ide awal masyarakat sebagai solusi permasalahan yang ada.

2. Realisasi ide kreatif ; menjadikan produkproduk yang dapat dipasarkan.

3. Penguatan sistem pendukung; tahapan yang memperkuat sistem pendukung dari aktivitas kreatif agar dapat terus 
berkelanjutan. Hal ini dilakukan dengan membangun jaringan dan mengembangkan sistem pendukung keberlanjutan aktifitas kreatif oleh stakeholder.

4. Penyediaan ruang basis aktivitas kreatif ; tahap penyediaan ruang berbasis pengembangan kreativitas.
5. Evaluasi Penyebaran aktivitas kreatif ; tahap evaluasi aktivitas kreatif yang terjadi dengan tujuan meningkatkan ide kreatif berikuitnya.

Tabel 1. Perencanaan Tahapan Kampung Pelangi

\begin{tabular}{|c|c|c|c|c|}
\hline $\begin{array}{l}\text { (1) } \\
\text { Pembentukan } \\
\text { ide kreatif }\end{array}$ & $\begin{array}{l}\text { (2) Realisasi ide } \\
\text { kreatif }\end{array}$ & $\begin{array}{l}\text { (3) Penguatan } \\
\text { sistem } \\
\text { Pendukung }\end{array}$ & $\begin{array}{l}\text { (4) Penyediaan } \\
\text { ruang basis } \\
\text { aktivitas kreatif }\end{array}$ & $\begin{array}{c}\text { (5) Evaluasi } \\
\text { aktivitas kreatif }\end{array}$ \\
\hline $\begin{array}{c}1 \\
\begin{array}{c}\text { Pembentukan ide } \\
\text { kreatif }\end{array}\end{array}$ & $\begin{array}{c}2 \\
\text { Realisasi ide kreatif }\end{array}$ & $\begin{array}{c}3 \\
\text { Penguatan } \\
\text { sistem } \\
\text { pendukung } \\
\end{array}$ & $\begin{array}{c}4 \\
\text { Penyediaan ruang } \\
\text { basis aktivitas } \\
\text { kreatif }\end{array}$ & $\begin{array}{c}5 \\
\begin{array}{c}\text { Evaluasi aktivitas } \\
\text { kreatif }\end{array}\end{array}$ \\
\hline $\begin{array}{ll}\text { a. } & \text { Keberadaan } \\
\text { ide kampung } \\
\text { pelangi } \\
\text { b. Pengembangan } \\
\text { ide kampung } \\
\text { pelangi } \\
\text { c. Identifikasi } \\
\text { masalah dan } \\
\text { potensi: } \\
\text { FGD } \\
\text { Kampung } \\
\text { pelangi dengan } \\
\text { Pengurus RT }\end{array}$ & $\begin{array}{ll}\text { a. } & \text { Menyusun program } \\
\text { kegiatan kampung } \\
\text { pelangi: } \\
\text { - } & \text { Sosialisasi } \\
\text { kampung pelangi } \\
\text { - }\end{array}$ & $\begin{array}{ll}\text { a. } & \begin{array}{l}\text { Menyusun } \\
\text { struktur } \\
\text { organisasi }\end{array} \\
\text { b. Menentukan } \\
\text { kerjasama } \\
\text { lintas sektor } \\
\text { c. Optimalisasi } \\
\text { partisipasi } \\
\text { warga } \\
\text { d. Perencanaan } \\
\text { Publikasi } \\
\text { media online } \\
\text { dan sosial } \\
\text { media }\end{array}$ & 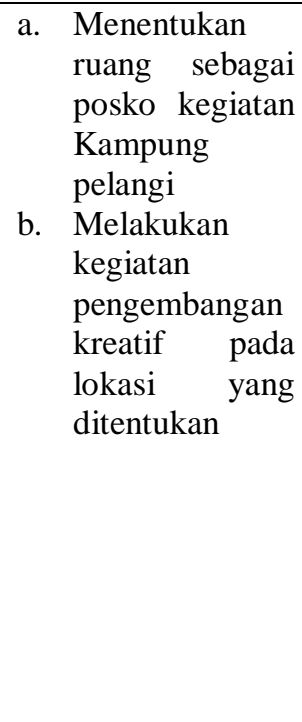 & $\begin{array}{l}\text { a. Evaluasi } \\
\text { penerapan ide } \\
\text { kampung } \\
\text { pelangi } \\
\text { b. Penerapan } \\
\text { solusi kreatif; } \\
\text { menyusun } \\
\text { rencana tindak } \\
\text { lanjut } \\
\text { c. Publikasi }\end{array}$ \\
\hline
\end{tabular}

\section{HASIL DAN PEMBAHASAN}

Pelaksanaan Pengabdian masyarakat telah dilakukan selama 3 bulan dimulai sejak Agustus sampai dengan Oktober 2018 di RT 03, RW 04 Kel urahan Kendangsari kota Surabaya. Kegiatan dilakukan lima tahapan yaitu :

\section{Pembentukan ide kreatif}

Tahap pengenalan dan pengembangan kreativitas pada masyarakat sebagai solusi permasa-lahan. Tahap ini dimulai dengan adanya inisiator berupa individu ataupun komunitas yang mem-bantu membangkitkan ide awal masyarakat (Devi, 2016). Pada kegiatan ini inisiator kampung pelangi adalah tim pengabdian masyarakat. Ide ini muncul sebagai hasil observasi selama proses KKN BBM UNAIR di kelurahan Kendangsari pada tahun 2017. Ide ini telah disetujui oleh pihak kelurahan Kendangsari melalui persetujuan sebagai mitra di propsal pengabdian masyarakat.

Survey untuk menentukan lokasi project Kampung pelangi dilakukan oleh ketua tim dengan Kasi Kesra Kelurahan Kendangsari. Tim pengabdian masyarakat menentukan RT 3 RW 4 sebagai lokasi project kampung pelangi dengan pertimbangan belum memiliki pengelolaan sampah bank sampah, padat rumah \& tersedia tembok sebagai media pengecatan, 
perilaku hidup bersih lingkungan masih rendah.

Langkah selanjutnya Identifikasi masalah dan potensi RT 03 RW 4 Kelurahan Kendangsari. Melakukan pertemuan diskusi dengan para pengurus RT 03 yang dilaksanakan di Rumah ketua RT 03. Hasil pertemuan diskusi teridentifikasi permasalahan jumlah sampah yang banyak dan belum dilakukan pengelolaan, masih rendahnya perilaku menjaga kebersihan lingkungan ditandai dengan sampah di jalanan dan got RT 03 karena perilaku buang sampah sembarangan. Warga RT 03 masih memiliki sifat gotong royong untuk kegiatan kerjabakti dan akan bersedia berpartisipasi dalam program pengabdian masyarakat. Dilakukan identifikasi kebutuhan untuk kegiatan kampung pelangi untuk kerjabakti, bank sampah, serta memunculkan jenis produk dari kampung pelangi.

2. Realisasi Ide Kreatif

a. Dilakukan sosialisasi ide kreatif kampung pelangi kepada warga di RT 03 dengan menjelaskan tujuan dan perencanaan pada saat ada kegiatan warga pada malam tirakatan 17 Agustus 2018. Warga memberikan respon positif dan menyampaikan dukungan untuk kegiatan pengabdian masyarakat kampung pelangi.

b. Persiapan kerjabakti pengecatan dilakukan dengan menyebarkan woroworo pelaksanaan kerjabakti kepada seluruh warga RT 03 dengan menyebarkan pengumuman pada selembar kertas yang ditempelakan di papan pengumuman, serta pemberitahuan melalui grup media sosial RT 03. Persiapan bahan dan perlengkapan melalui pengadaan bahan cat serta peralatan kuas dilakukan pembelanjaan oleh tim pengabdian masyarakat bersama dengan pengurus RT 03.

c. Kerjabakti Bersama untuk pengecatan dilaksanakan secara serentak setiap hari Minggu mulai tanggal 26 Agustus sampai dengan 7 Ooktober 2018. Yang terlibat dalam kegiatan adalah : Tim Pengabdian masyarakat, Mahasiswa
Fakultas Keperawatan UNAIR, Pengurus RT, Warga RT 03 (anakanak, Karang Taruna, Ibu-Ibu , bapakbapak, lansia), dan pihak Kelurahan Kendangsari. Selain kerjabakti masal setiap hari minggu, warga secara mandiri melakukan pengecatan pada malam hari pada saat waktu luang di bawah koordinasi ketua RT 03. Sasaran pengecatan mulai dari gerbang masuk RT 03 di Jl. Kendangsari gang XIV sepanjang jalan sampai perbatasan dengan RT 04 berupa pagar, tembok rumah, toko, warung, dan gapura.

d. Pelatihan Batik Celup

Pelatihan Batik Celup Shibori dilaksanakan pada hari Minggu 30 September 2018 di RT 03 RW 04 Jl.Kendangsari gang 14 No.18 Surabaya. Kegiatan pelatihan yang diikuti 15 ibu-ibu PKK. Dalam kegiatan ini tim Pengabdian masyarakat bekerjasama dengan UMKM Grand Batik dari Sidoarjo untuk memberikan pelatihan batik celup.

e. Sosialisasi Bank Sampah

Kegiatan sosialisasi Bank sampah dilakukan pada hari Jumat tanggal 5 Oktober 2018 pada saat kegiatan PKK RT 03. Pada kegiatan ini bekerjasama dengan Bank Sampah Induk Surabaya (BSIS) sebagai unit pengelola bank sampah di surabaya untuk memberikan materi sosialisasi Bank Sampah. Diberikan pula penyuluhan tentang pentingnya menjaga kebersihan lingkungan untuk kesehatan diberikan oleh tim pengabdian masyarakat Elida Ulfiana, S.Kep.,Ns.,M.Kep. Pada kegiatan tersebut disampaiakan materi tentang mengenal sampah, tujuan pengelolaan bank sampah, dan mekanisme bank sampah. Hasil dari kegiatan tersebut adalah pengetahuan tentang sampah dan pengelolaan bank sampah semakin meningkat, adanya sikap untuk membentuk bank sampah di RT 03.

3. Penguatan sistem pendukung.

Dilakukan perencanaan menyusun pengorganisasian warga dalam pembentukan kampung pelangi kendangsari di RT 03, dibentuk 
koordinator, tim kreatif, tim perlengkapan, tim konsumsi,dan tim humas. Keberadaan tim ini mampu mengkoordinasi warga selama pelaksanaan kegiatan kerjabakti dan kelanjutannya.

Melakukan kerjasama lintas sektor untuk mendukung pelaksanaan pembentukan kampung pelangi melalui pengiriman proposal kemitraan kampung pelangi. Proposal telah dikirimkan ke PT SIER Surabaya, PT AVIA AVIAN, PT Nippon Paint, Indomie, PT Unilever, Dinas Kebersihan dan Pertamanan Surabaya.

Perencanaan Publikasi setelah kegiatan kerjabakti pengecatan, pelatihan batik dan bank sampah akan di publikasikan ke masyarakat luas melalui pemberitaan di media cetak atau online.

4. Penyediaan ruang basis aktivitas kreatif Menentukan ruang sebagai Posko, Pihak RT 03 menyediakan posko di gedung TPQ Al Hikmah karena gedung RT 03 dalam tahap renovasi. Untuk kegiatan pelatihan serta sosialisasi Bank sampah dilakukan di salah satu rumah warga.

5. Evaluasi

Evaluasi kegiatan ide kreatif dilaksanakan pada hari minggu tanggal 7 Ooktober 2018. Kegiatan ini dilakukan setelah kegiatan kerjabakti pengecatan yang dihadiri oleh tim pengabdian masyarakat, mahasiswa, warga RT 03. Hasil evaluasi disampaikan bahwa RT 03 terutama di sepanjang jalan JL. Kendangsari gang XIV sudah bernuansa warna warni. Kreatifitas warga tanpak saat mendesain gambar atau motiv dalam pengecatan. Keterlibatan seluruh kalangan usia di RT 03 menunjukkan adanya proses pemberdayaan telah terjadi. Kerjasama lintas sektor akan ditindaklanjuti oleh pihak warga RT 03 yaitu dengan rencana penghijauan dari bantuan tanaman hias dan kompos dari Dinas Pertamanan. Perencanaan unit bank sampah di RT 03 akan ditindaklanjuti oleh pengurus RT 03 dengan pembentukan pengurus Bank Sampah. Hasil pelatihan batik celup telah membentuk sikap positif para ibu-ibu PKK sebagai inisiasi kewirausaan di kampung pelangi kendangsari.

Publikasi keberadaan kampung pelangi telah dilakukan pada media online di web ners.unair.ac.id, Warta UNAIR, bidik.news, jatim.sindonews, new.okezone.com, beritanusa.com, dan media cetak Jawa Pos pada tanggal 11 Oktober 2018

\section{KESIMPULAN}

Kegiatan Pengabdian Masyarakat berhasil merintis Kampung Pelangi Kendangsari. Metode Pemberdayaan masyarakat yang telah diterapkan melalui strategi kampung kreatif telah mampu menumbuhkan semangat dan kreatifitas masyarakat RT 03 untuk berpartisipasi dalam mewujudkan kampung pelangi di RT 03. Pengetahuan warga tentang sampah juga meningkat, serta terbentuk sikap positif untuk melakukan pengelolaan melalui bank sampah. Kaum ibu telah memiliki ketrampilan membuat batik celup yang dapat menjadi rintisan dibentuknya UMKM sebagai kreatifitas memperkuat keberadaan Kampung Pelangi Kendangsari.

\section{UCAPAN TERIMAKASIH}

Kegiatan ini didanai oleh RKAT Fakultas Keperawatan Universitas Airlangga tahun anggaran 2018 melalui skema Hibah Pengabdian Masyarakat Fakultas Keperawatan Universitas Airlangga.

\section{DAFTAR PUSTAKA}

Charles Landry, Franco Bianchini. The Creative City, https://www.demos.co.uk/files/thecreati vecity.pdf

Devi Hanurani Sugianti, Agus S. Ekomadyo, (2016), Strategi Kampung Kreatif sebagai Upaya Perbaikan Lingkungan Kota menurut Kerangka Pemenuhan Kebutuhan Manusia Studi Kasus : Kampung Jambangan. Temu Ilmiah IPLBI 2016

Dita Puspa Dewanda, Ernawati Hendrakusumah, Transformasi Permukiman Kumuh Kreatif Di Kota Bandung (Studi Kasus: Kampung Wisata Akustik Di Cicadas, Kampung Kreatif Pasundan, Dan Kampung Taman Hewan). Proceeding of Urban Plan Engineering. http://karyailmiah.unisba.ac.id/index.ph p/PWK/article/view/2268 
Heryati, (2011), Kampung Kota Sebagai Bagian Dari Permukiman Kota Studi Kasus : Tipologi Permukiman Rw $01 \mathrm{Rt}$ 02 Kelurahan Limba B Dan Rw 04 Rt 04 Kel.Biawu Kecamatan Kota Selatan Kota Gorontalo. Jurnal Inovasi Vol 08 No.03 Tahun 2011.

http://ejurnal.ung.ac.id/index.php/JIN/ar ticle/view/728/671.\%20\%5B15\%20Sept ember\%202016
KKN BBM 57. Laporan Akhir KKN BBM Tematik 57 kelurahan Kendangsari, LP4M Uniar, 2017

Nugroho, A.C (2009), Kampung Kota Sebagai Sebuah Titik Tolak Dalam Membentuk Urbanitas Dan Ruang Kota Berkelanjutan. http://ftsipil.unila.ac.id/ejournals/index.php/jrek ayasa/article/viewFile/20/pdf 